\title{
Coastal Morphodynamics and Human Impacts
}

\section{Roshan T Ramessur*}

Department of Chemistry, Faculty of Science, University of Mauritius

Keywords: Coastal erosion and accretion rehabilitation; Coastal protection; Coastal engineering solutions.

It has long been obvious that our beaches have evolved with time in response to factors including the supply of sediment, the action of waves and currents, geological constraints, structures and sea level rise. The coastal zone is a delicate dynamic balance between the powerful driving forces of the ocean such as cyclones, waves, surges and tides as well as the reef-lagoon-beach ecosystem. It offers protection against these processes, as well, as producing sediments for the beaches and should be viewed as one complex multidisciplinary entity with the various conflicting uses and activities taking place within the zone. There is a constant need to rehabilitate and improve eroded shorelines and encourage the use of environmental technology for coastal rehabilitation. Alongshore sediment transport takes place due to topographical characteristics and coastal structures and revetment may cause shifts in erosion areas. Design processes for countermeasures are crucial for the preservation of the natural characteristics of the coastal and marine environment to mitigate the impacts of sustained erosion of the shoreline. The failure of coastal defences fortunately happens rarely but can have dramatic consequences as large scale flooding or a high rate of coastal erosion can follow. Shoreline retreat is one of the symptoms of an eroding coastline, which can eventually lead to the loss of settlements, such as villages and towns. Countries are now increasingly being affected mostly by hydrogeometeorological hazards and disasters, namely, floods, mass movements (e.g. erosion, landslides and siltation), tropical cyclones, hurricanes, tsunamis, swells and storms due to climate change [1-4]. The Special Issue in the Journal of Coastal Development on "Coastal Morphodynamics and Human Impacts" will deal with papers on erosion and accretion, coastal protection and rehabilitation and coastal conservation plan, shoreline modifications and human impacts. Articles can deal with coastal evolution and sea level rise, seasonal variation, storm response, conceptual models as scientific and engineering tools for a variety of coastal landforms and environments and soft coastal engineering solutions.

\section{References}

1. Clark JR (1992) Integrated management of coastal zones. FAO Fisheries Technical Paper 327

2. Linden O (1995) Integrated coastal zone management in Eastern Africa including the Island states. Coastal Management Center, Philippines.

3. SARUA (2010) Climate Change, Adaptation and Higher Education: Securing our Future. SARUA Leadership Dialogue Series 2.

4. Ramessur RT (2002) Anthropogenic driven changes with focus on the coastal zone of Mauritius, south-western Indian Ocean. Regional Environmental Change 3: 99-106
${ }^{*}$ Corresponding author: Roshan T Ramessur, Department of Chemistry, Faculty of Science, University of Mauritius, E-mail: ramessur@uom.ac.mu

Received October 01, 2013; Accepted October 03, 2013; Published October 09, 2013

Citation: Ramessur RT (2013) Coastal Morphodynamics and Human Impacts. J Coast Dev 16: e104. doi: 10.4172/1410-5217.1000e104

Copyright: @ 2013 Ramessur RT. This is an open-access article distributed under the terms of the Creative Commons Attribution License, which permits unrestricted use, distribution, and reproduction in any medium, provided the original author and source are credited. 